\title{
Investigar en tiempos de crisis y pandemia
}

\author{
Marta Bonaudo ${ }^{1}$
}

La dinámica actual del mundo le ofrece al cientista social y a los historiadores en particular, un espectacular laboratorio para analizar el devenir del siglo XXI que, como diría Eric Hobsbawn, comenzó con la crisis de los Estados de Bienestar en la década de 1970. Desde ese entonces el orden social dominante ha atravesado una larga sucesión de crisis sociales, políticas y económicas que larvadamente han ido poniendo en cuestión las bases del paradigma en la que el mismo se sustenta. Pero, tal vez, como le sucedió a esos personajes de Chaucer o de Bocaccio conmovidos por las crisis del siglo XIV y la peste, sus actores todavía no podían analizar e interpretar la profundidad de los desafíos que debían enfrentar. Sin embargo, con diversos niveles de conciencia aquellos del siglo XIV -campesinos, trabajadores urbanos, artesanos, mercaderes y banqueros- protagonizaron impactantes movilizaciones que fueron poniendo en cuestión tanto las relaciones sociales como las formas de dominación del orden feudal.

Hace días, en un comentario radial se hablaba de la clarificación de las aguas del Paraná -ante la ausencia del envenenamiento cotidiano al que están sometidas- permitiendo ver algo impensado en «tiempos normales»: los cardúmenes que lo recorren. Creo que en el orden social contemporáneo ha sucedido algo similar ya que la pandemia ha dejado al descubierto las entrañas mismas del sistema. Es pues el momento justo para que el historiador se introduzca de lleno en la dinámica de su sociedad, esgrimiendo sus herramientas teóricas, conceptuales, desplegando su potencial metodológico con miras a colaborar en la búsqueda de respuestas ante los nuevos interrogantes que la actual situación genera.

Como lo ha aprendido, particularmente en este breve siglo XXI, del mismo modo que los otros cientistas sociales tiene que dejar atrás las anteriores certidumbres y comenzar a lidiar nuevamente con las pregun-

${ }^{1}$ Universidad Nacional de Rosario. Consejo Nacional de Investigaciones Científicas y Técnicas. Contacto: martabonaudo@gmail.com 
tas , especialmente con la del papel jugado por lo imprevisible, lo incierto sobre una dinámica social determinada.

El primer disparador, sin dudas, es el corona virus: ¿un imprevisto?, ¿la punta del iceberg?, ¿̇un «daño colateral» consecuencia del funcionamiento del orden? Lo objetivo es que su aparición ha descorrido, una vez más, veloz y descarnadamente, el velo de ignorancia que ocultaba si es que todavía era posible- los desequilibrios, las asimetrías, el fortísimo nivel de exclusión de las mayorías sociales en el capitalismo globalizado actual. Y entonces, ante los ojos del investigador se despliegan, otra vez, viejos y nuevos tópicos que hace décadas viene explorando en relación a la contemporaneidad: las formas de la dominación; el sentido de la política y su capacidad de transformación; el porqué y para qué de los Estados; la tensión entre el Estado y el mercado; las pugnas por la hegemonía internacional o nacional; los modelos de desarrollo; las condiciones de distribución social; las posibilidades de acceso a una verdadera igualdad y libertad en sociedades con altos niveles de exclusión y fuertes asimetrías en su interior; el juego de los tiempos -acontecimiento, coyuntura, proceso-; las interacciones entre lo micro y lo macro; entre lo local, lo regional, lo nacional; las tensiones entre lo individual y lo colectivo; entre lo racional y lo emotivo.

Este último eslabón ha cobrado hoy nuevos significados, significados que en otras épocas el arte y la literatura recuperaban casi en soledad. Sin embargo, en estas últimas décadas los cientistas sociales están prestando mucha atención a tales dimensiones de la realidad y, especialmente, los historiadores culturales de las emociones. Justamente, el aislamiento social no sólo ha provocado quiebres en la relación racionalidad-emociones sino que ha evidenciado la potencia de las sensaciones, la afectividad, los vínculos humanos y la necesidad de los otros sobre las prácticas y las dinámicas sociales en todo tiempo y lugar.

Las preguntas no respondidas abren el abanico para nuevas búsquedas, para diferentes exploraciones. No obstante, algo definido parece estar surgiendo de las entrañas mismas de la crisis y es la certeza de que la pandemia no proporcionará las alternativas superadoras, estas están en manos de los actores o agentes de cada comunidad, de cada sociedad.

El historiador, que es un actor social más de los tantos involucrados en el proceso, comienza en la coyuntura a observar y analizar posibles respuestas. Dos dimensiones parecen emerger ante su mirada con mayor significación en el maremágnum de la crisis. En primer lugar, la 
que recupera el valor y la capacidad de transformación de la política así como el empoderamiento que de ella han hecho la gran mayoría de los actores atravesados por esta crisis en ese doble accionar: aislarse y solidarizarse. Sin esa toma de conciencia -más allá de los miedos y de las angustias- ninguna orden estatal hubiera podido ponerse en práctica. En segundo lugar, la que apela al conocimiento, a los cientistas de todos los campos para superar los estragos físicos, psíquicos, económicos, ambientales y sociales que la propia crisis y la pandemia han provocado.

Estamos aún en la superficie del problema pero la observación, en este caso participante, es el primer paso. Ahora cabe penetrar en la compleja trama del proceso. El camino es lento, arduo, seguramente se producirán fracasos, retrocesos pero también logros. No tenemos hoy el hilo de Ariadna para que nos guíe pero sí una base de conocimientos previos que torna posible menores fallos al formular las preguntas que orientan toda investigación. 